\title{
Genealogies and Assemblages of Resistance
}

\author{
Jeanne Bouvier's Struggles in 'Le Travail à Domicile'
}

\author{
Maria Tamboukou
}

This chapter draws on extensive archival research into the papers of Jeanne Bouvier, a French trade unionist and activist in the garment industry at the turn of the nineteenth century. ${ }^{1}$ Bouvier was a leading figure in transnational debates around the problem of 'le travail à domicile' or home work, and throughout her life she struggled to place and maintain home-based work on the agenda of the international labour movement. Her work had a major impact not just on the level of state regulations and labour policies, but also within the academic and intellectual circles of her time. In writing a major economic study of the lingerie industry in France, Bouvier also left her imprint on how the problem of home-based work has been studied, understood, analysed and, most importantly, addressed. Many of these questions that were raised at the turn of the nineteenth century are both pertinent and unresolved even today, and thus a genealogical investigation through the lens of assemblage theories can offer rich and useful insights for contemporary research and policies.

In my research into Bouvier's papers, I have followed genealogical trails of her involvement in the politics of le travail à domicile as a worker, as a trade unionist and as the author of a major historical study of the lingerie industry in France. ${ }^{2}$ While addressing the question of how to inscribe women workers' resistance within the site of home-based work, I suggest that the notion of assemblage is a useful theoretical tool that can help us rethink resistance in the histories of women's involvement in the garment industry and beyond. As I further discuss later on in the chapter, assemblage approaches highlight material and symbolic entanglements of heterogeneous components through

1 This chapter draws on my research project of writing a feminist genealogy of the seamstress, looking at submerged and marginalized histories of women working in the garment industry in the nineteenth and twentieth centuries. See Maria Tamboukou, Sewing, Fighting and Writing: Radical Practices in Work, Politics and Culture (London, 2015); Gendering the memory of work: women workers' narratives (London, 2016).

2 Jeanne Bouvier, La lingerie et les lingères (Paris, 1928).

(C) MARIA TAMBOUKOU, 2022 | DOI:10.1163/9789004499614_013

This is an open access chapter distributed under the terms of the CC BY-NC-ND 4.o license. 
which provisional entities and relations emerge and throw light on the relations between stability, transformation and change.

The chapter unfolds in three parts: first, I follow genealogical lines of lived experiences in the garment industry; then, I consider agonistic responses to the acute problem of industrial home work through the lens of assemblage theories; and finally, I review Bouvier's historical study of the French lingerie industry as an early exemple of assemblage analytics at work.

\section{Genealogies and Archives: Jeanne Bouvier's Lived Experiences of Industrial Home Work}

As a Nietzschean insight reconfigured in Michel Foucault's analytics, genealogy is concerned with the processes, procedures and apparatuses whereby truth and knowledge are produced. ${ }^{3}$ Genealogy writes the history of the present: it problematizes the multiple, complex and non-linear configurations of the socio-political and cultural formations of modernity. In the context of my research, the questions are as follows: What were the conditions of possibility for industrial home work to emerge as the feminine labour problem par excellence? How has it been marginalized and neglected in the social and political movements of the nineteenth and twentieth centuries? Why is this still a troubling issue dividing state policies as well as the international labour movement? And, finally, how can we reassemble traces of resistance in the writing of feminist labour histories?

In addressing the historicity of such questions and problems of the present, genealogy conceives subjectivities and social relations as an effect of the interweaving of discourses and practices, which it sets out to trace and explore. But instead of seeing history as the continuous development of an ideal schema, genealogy is oriented towards discontinuities. Throughout the genealogical exploration there are frequent disruptions, uneven and haphazard processes of dispersion that call into question the supposed linear evolution of history. Industrial home work is a paradigmatic case of uneven historical developments, and its study seriously deviates from the canon of analysing industrial formations in modernity. As Eileen Boris has aptly pointed out, "the history of industrial home work and its regulation over the last century illustrates the historical construction of gender and the gendering of state action."4

3 Michel Foucault, "Nietzsche, Genealogy, History", in Paul Rabinow (ed.), The Foucault Reader (Harmondsworth, 1986), pp. 76-100.

4 Eileen Boris, Home to work: Motherhood and the Politics of Industrial Homework in the United States (Cambridge, 1994), p. 4. 
As a methodological approach, "genealogy is grey, meticulous and patiently documentary"; 5 it is the art of archival work par excellence. However, Foucault wrote very little about the nuts and bolts of his archival work. It is from his collaborator Arlette Farge's influential text, Le Gout de l'Archive, ${ }^{6}$ that we can literally have a taste of some of the theoretical, methodological and affective practices in the archive, and it is from Farge's work that my overall "archival sensibility" 7 vis-à-vis forgotten documents, subsumed life-stories and marginalized figures emerges.

Jeanne Bouvier (1865-1964) was one of those marginalized figures that emerged from the archive of women's work in the garment industry. She was born in the south of France to a peasant family and became a silk worker at the age of eleven after a financial disaster that left her family penniless. In 1879 she moved to Paris, where she worked as a domestic and finally trained as a dressmaker. She got involved in labour politics and became an ardent trade unionist in the French garment industry, as well as a leader in the international women's labour movement. After retirement she threw herself in the pleasures of research and wrote four historical studies, as well as her Mémoires. ${ }^{8}$

A leitmotif that runs through Bouvier's writings is the problem of industrial home work: it becomes a refrain, a theme that is repeatedly experienced, narrated, contested, analysed, theorized, understood. Her work became so influential that research students would ask her for help and advice: "I am a law student doing my doctoral thesis on the application of the July 10, 1915 law on the minimum salary of industrial home workers", Jeanne Odry wrote to Bouvier, asking for information given her great "competence in the subject". ${ }^{9}$ In a later letter she wrote that her thesis had been successfully defended, thanks to Bouvier's invaluable advice and help. ${ }^{10}$ Bouvier's papers at the Bibliothèque Historique de la ville de Paris (BHDP) include a series of lengthy letters from researchers asking for her advice, mostly about women's work, well before any

$5 \quad$ Foucault, "Nietzsche, Genealogy, History", p. 76.

6 Arlette Farge, Le goût de l'archive (Paris, 1986).

7 Niamh Moore, Andrea Salter, Liz Stanley and Maria Tamboukou, The Archive Project: Archival Research in the Social Sciences (London, 2016).

8 Jeanne Bouvier, Mes Mémoires: Une syndicaliste féministe, 1876-1935 (Paris, 1983 [1936]).

9 Jeanne Odry to Bouvier, Paris, 12 June [no year], Bibliothèque Historique de la Ville de Paris, Archives Marie-Louise Bougle, Fonds Jeanne Bouvier [hereafter BнVP/Амв/FJB], Boite 18, Le Travaille à Domicile.

10 Odry to Bouvier, Paris, 4 February [no year], ibid. Although there is no year in the date of the letter, we know that Odry's thesis was published in 1924. See Jeanne Odry, Application de la loi du 1o juillet 1915 sur le salaire minimum des ouvrières à domicile (Paris, 1924). 
of her own books had been published. This is what Paul Boyaval, a well-known writer on the home sweating system, wrote to her in December 1920:

\section{Dear Mademoiselle Bouvier,}

Perhaps you still remember the undersigned author of a thick volume entitled "The Struggle against the Sweating System" that I had the pleasure to address to you as a tribute in 1912.

Unfortunately, I have been at war for five years and I was not able to continue following this scary problem of domestic work. I would now like to study the question at the point where it was in 1912 and I could not think of a better person than you to brief me on the current situation of the problem and on everything that has been done on this subject in the last ten years. ${ }^{11}$

It is not surprising that so many researchers got interested in the phenomenon of industrial home work at the turn of the nineteenth century. What is particular to Bouvier, however, is that it became the focal point of her lifelong struggles and agonistic politics. Among the two boxes of her correspondence (Boîte 17/ 1-2) there is a special Dossier (3) on her epistolary communication with international syndicalists, including letters from the US, the UK, Canada, Argentina, Chile, China, Austria, Belgium, Italy, Spain, Switzerland and the Netherlands. Boîte 18 on "La Travail a Domicile" additionally includes letters from Poland, while Boîte 23/Dossier 2 includes all the proceedings and reports from the 1919 Washington conference and the International Federation for Working Women (IFWW) that was subsequently established. Let us then trace this leitmotif to its beginning, Bouvier's experiences as a child worker in the silk factories of her home region, Le Dauphiné.

Bouvier's initiation into the hardships of industrial home work was a direct consequence of the financial disaster that befell her family due to a phylloxera infestation that made them sell everything and dislocated them to a nearby village, Saint-Symphorien-d'Orzon. It was there that Bouvier started working in a silk-throwing factory: "My parents, who until then had lived in relative comfort, were forced to sell everything: house, meadow, vineyard and even furniture and various belongings. [...] It was a disaster",12 she wrote in her memoirs.

From the very beginning of her life as a silk worker Bouvier learnt that there were no laws to protect children at work, and even if there was some kind of

\footnotetext{
11 Paul Boyaval to Bouvier, 23 December 1920, B HVP/AM B/FJB/, Correspondance, Boite 17.2.

12 Bouvier, Mes Mémoires, pp. 55-56.
} 
restrictive legislation, it was never applied. "A law had been passed in 1840 making it illegal to have children under the age of 12 work more than 8 hours, but it was never enforced. This is why I was working 13 hours", she wrote. ${ }^{13} \mathrm{Her}$ workday started at 5 in the morning; there was a break for la soupe at 8 a.m. and another break at midday for le déjeuner. Despite the five extra hours she was illegally made to work for, her wages were not enough to bring food to her family who were dependent on her, since her father had abandoned them very soon after their internal migration. "I was proud to bring my mother the fruits of my labour", ${ }^{14}$ she wrote, but she also had to work at home to supplement their meagre income; despite her efforts bread was still scarce in the family:

I remember one time amongst others when I went without eating for nearly two days. That evening when I came home from the factory, I started to work. My mother spent the night with me, shaking me whenever, in spite of myself, I began to fall asleep. She was telling me, "Don't fall asleep. You know very well that you mustn't sleep. Tomorrow we won't have any bread." I was making superhuman efforts to stay awake. It was very cold. Snow was falling against the windowpanes. Despite all this torture I continued to work until 4.30 in the morning, at which time I got ready to return to the factory. ${ }^{15}$

Bouvier's first job in the garment industry of Paris, where she moved in 1879, was at a milliner's atelier. She was happy there, in the company of so many fellow-workers. She picked up the milliner's skill easily and soon began to earn "a reasonable livelihood". ${ }^{16}$ But her wage cycle followed the seasonal rhythms of the trade: "In the high season, my wages went from 30 to 40 francs a week, and sometimes up to 45 , to drop back to 12 or 15 francs in the low season."17 The fluctuations in her earnings, and particularly the need to save for the lean season, led her to take on additional sewing work at home: "I was able to make aprons, skirts, caracos and camisoles", 18 she wrote. It was not only the daily bread, but also the need to have a home of her own that made her take on extra home work: "I continued to live frugally and was still doing extra work to keep myself afloat. I wanted to move for I wanted a room with a fireplace.

\begin{tabular}{ll}
\hline 13 & Ibid., p. 57. \\
14 & Ibid. \\
15 & Ibid., p. 59. \\
16 & Ibid., p. 81. \\
17 & Ibid. \\
18 & Ibid., p. 85.
\end{tabular}


Yes, I wanted to offer myself the luxury of a fireplace."19 When she finally lost her job as a milliner due to the many crises that the Parisian garment industry went through at the turn of the century, industrial home work became a means of survival. Bouvier has vividly recounted her experience of sewing plackets on corsets, along with a neighbour-friend, in her Mémoires:

We would get up early and sleep late. When the work was finished, we went to the employer to return it; he told us that he would pay us $11.5^{\circ}$ francs for the work, but after the cost of the ribbon was deducted, only 4 francs remained for us! And we had worked for two days from 5 o'clock in the morning till 1o o'clock at night! Judging this work as very bad, we did not take it up again! ${ }^{20}$

It is interesting that Bouvier's reminiscences of industrial home work conclude with a decision "not to take it up again". This was a choice not open to everyone. Bouvier's contemporary, Marguerite Audoux, who also had an ugly taste of industrial home work as a newcomer in the fashion metropolis at the turn of the twentieth century, wrote: "On my arrival in Paris, I had to earn my living at all costs, and I had to accept any kind of needlework that was offered."21 Bouvier was not a newcomer in Paris when she took the decision to turn down industrial home work for its abject conditions. And yet, throughout her life, even after she had found a position in an atelier and become a successful dressmaker, she would always work at home to supplement her income and as a cushion for hard times:

For some time, I had clients who would have me work at their homes during the lean season. I would thus escape the period of unemployment, which gave me a certain comfort. In this way, I never missed work. But during the high season, these clients brought me additional work. Apart from the days spent at the atelier, I always had some orders to do at home to satisfy my personal clientele. After my workday I therefore had to impose long late-night vigils on myself. My time was divided up like that: get up at 4 o'clock; work at home until 8; then get ready and have breakfast within half an hour; at 8.30 leave for the atelier, where I arrived at 9 o'clock and left only at 8 or 9 in the evening. I would rush home, eat

\footnotetext{
$19 \quad$ Ibid., p. 88.

$20 \quad$ Ibid., p. 86.

21 Marguerite Audoux, Marie-Claire's Workshop, trans. Frank. S. Flint (New York, 1920), p. 119.
} 
dinner in a hurry, and get back to work until midnight, when I finally went to bed, to sleep till 4 o'clock in the morning. ${ }^{22}$

What emerges from Bouvier's recollections of her solitary bio-labour rhythms, as forcefully recounted above, is that while in classical Marxist analysis the industrial conception of time is based on the requirement that "the worker relinquishes formal control over his or her labour time during the stipulated workday by exchanging it for pay,"23 things become much more complicated in the temporal organization of industrial home work. Historically, men have also worked at home-based sweatshops; but unlike women who have welcomed it as an opportunity, its drudgeries notwithstanding, men have always resisted work at home. As Joan Scott has noted in her influential study of the politics of work and family in Parisian trades of the nineteenth century, working at home was not a central issue or a problem per se for Parisian seamstresses. ${ }^{24}$ Rather, they were concerned with seeking regulation of home-based work and especially higher wages, as arrangements of working from home not only enabled them to work and look after their family, but also safeguarded their professional identities as qualified seamstresses. Tailors, on the other hand, were very much against home-based work and fought for the right to do work only at workshops. In their context, it was shop-based work that protected their professional identity and not the level of wages. Nancy Green has further shown that such debates were carried on in the trade unions of the Parisian garment industry in the first half of the twentieth century, which nevertheless remained unregulated overall: "While workers, unions and the state sought greater protection and standards for labour conditions, the garment industry remained reticent to restrictive rules." ${ }^{25}$ Moreover, home-based women needleworkers came to represent "the opposite of the atheist, materialist worker of the revolutionary committees" 26 in the socialist political discourse of their times.

There is a distinct gender issue here, which, as Scott has argued, has been largely ignored by labour historians: the way the home has been historically constituted as a desired workplace for women, and thus created the possibility of conflation of waged and unwaged labour for women, right up to the

\footnotetext{
22 Bouvier, Mes Mémoires, pp. 97-98.

23 Samuel Bowles and Herbert Gintis, Schooling in Capitalist America (London, 1976), p. 57.

24 Joan W. Scott, Gender and the Politics of History (New York, 1988).

25 Nancy Green, Ready to Wear, Ready to Work: A Century of Industry Immigrants in Paris and New York (Durham and London, 1997), p. 84.

26 Cited in Judith Coffin, The Politics of Women's Work: The Parisian Garment Trades, 1750-1914 (Princeton, 1996), p. 175 .
} 
present day. ${ }^{27}$ Women's memories of work bring this neglected dimension of the political economy of work to the surface and show that there is a marginalized genealogy of struggles, such as Bouvier's life-long passion for the regulation and protection of industrial home work-le travail à domicile — to which I now turn.

\section{$2 \quad$ Bouvier's Agonistic Politics and Assemblage Theories}

As Bouvier has recounted in her memoirs, it was through her conversations with enlightened bourgeois women that she learnt about trade unionism and feminism as options in her life of struggle:

In 1897, a feminist journal was launched by Mme Marguerite Durand: $L a$ Fronde, a daily edition on feminist rights. [...] One of my clients, Mme Norat, was an ardent feminist. She became an assiduous reader of this journal and while I was trying her dresses, she would be talking to me about women's rights and the injustices of the law with regard to women. In this way, every fitting session was a lesson in feminism. [...] One day she told me: "I am surprised that an intelligent woman like you has not subscribed to the union of your trade. [...] There is a trade union for seamstresses, lingères and similar parties. I often see notifications of this union in La Fronde." There was indeed a campaign in La Fronde for women workers to become union members. This invitation to unionize seemed to me extraordinary. Unionize? Me? Why? I confess, I did not understand anything. The very idea seemed strange to me. But the lady was tenacious and every time we met, she would ask me: "Well, Mademoiselle Jeanne, have you become a member of the union yet?"28

Bouvier's encounter with an enlightened middle-class feminist actively propagating syndicalism was not accidental. There was a lot of agitation and a number of rebellious strikes in the garment industry in the first decade of the twentieth century, where women needleworkers took centre stage. ${ }^{29}$ In doing so, they followed a genealogical line of agonistic politics that went back to the July monarchy and the emergence of the first autonomous

27 Scott, Gender and the Politics of History, p. 93.

28 Bouvier, Mes Mémoires, p. 101.

29 See, amongst others, Green, Ready to Wear, Ready to Work; Tamboukou, Gendering the Memory of Work. 
feminist movement in France, which was led by seamstresses. ${ }^{30}$ Gender relations within the garment industry, as well as within the trade unions, were at the forefront of the confrontation and thus attracted a lot of attention from various feminist groups active in Paris at the time. Marguerite Durand and the group around La Fronde actively supported the women strikers, making connections with wider feminist demands. As Coffin has succinctly put it, "La Fronde saw the [1901] strike as a feminine prise de parole, a demonstration of women workers' seriousness of purpose and capacities for public action and speech." ${ }^{31}$

But these strikes were also the reason for Bouvier's initial resistance to the idea of joining the union. "The Bourse du Travail was not totally unknown to me", she wrote, ${ }^{32}$ linking it to the revolutionary moments when workers had joined students at the barricades of the Quartier Latin. "These memories of the Bourse du Travail were not exactly a sufficient recommendation for my participation in the seamstresses' union", she boldly concluded..$^{33}$ Here again, Bouvier's aversion to syndicalism due to the dark memory of its riots had been recognized as a problem by the sociologists of her time. As Aline Valette, a feminist social reformer and factory inspector, wrote in La Fronde in 1898, women needleworkers were particularly difficult to unionize: "Their isolation makes them believe that they are totally and perpetually powerless, and they back off from any initiative." ${ }^{34}$

Despite her initial scepticism, however, Bouvier not only joined the union but soon rose in its hierarchy and became one of its few women leaders, not only in France but in the international workers' movement. Her papers include many letters from women trade unionists all over the world with whom she was in correspondence throughout her life, and some of whom she would meet in person when they happened to visit Paris. Below is a letter that Mary Anderson, Director of the Women's Bureau of the US Department of Labour, sent Bouvier on 20 May 1926, by way of introducing two friends, Amy G. Maher and Rachel Gallagher, who would be coming to Paris for the International Meeting of Women's Suffrage and who were interested in investigating the conditions of women workers in industry in France.

30 See Tamboukou, Sewing, Fighting and Writing.

31 Coffin, The Politics of Women's Work, p. 178.

32 Bouvier, Mes Mémoires, p. 101.

33 Ibid., p. 102.

34 Aline Valette, "Le Travail des femmes: Ouvrières et syndicats", La Fronde, 10 July 1898. 
My dear Mlle Bouvier:

This letter will introduce you to Miss Amy G. Maher and Miss Rachel Gallacher, both from Toledo, Ohio. Miss Maher is the Chairman of the Ohio Council of Women and Children. This Council is composed of the different women's organizations in the State, together with the State Federation of Labour and their work, no doubt as Miss Maher will explain. Miss Gallacher is Miss Maher's very able assistant. They are both very anxious to see the labour movement of France and if there are any meetings which interested persons may attend, they may be allowed to do so. ${ }^{35}$

Not only did Bouvier meet the two women from Ohio, she also developed a life-long correspondence with Maher, who kept sending her personal letters and Christmas cards till the end of her life. They can now be found in the two boxes holding Bouvier's correspondence; the fact that she kept and filed them among her papers is a mark of their emotional importance in the solitude of her life. ${ }^{36}$ For Bouvier, working with and developing personal friendships within a network of international women was amongst the pleasures of being a feminist and a trade- unionist. It was these friendships and connections that kept her going through difficult times with her comrades in France. "Thank you so much for your lovely New Year's Card. I was so pleased to get it and hear from you again. I know we have so much in common and are never able to express it to one another", 37 Anderson wrote to her on 15 January 1925.

It was indeed Bouvier's struggles for the regulation of home-based work that made her internationally famous. Her papers reveal how methodically and tirelessly she worked throughout her life, to put industrial home work on the agenda of French and international labour policies and politics. As already noted in the previous section, the phenomenon of industrial home work was deeply embedded in the traumatic memories and experiences of her own working life.

I could not stay indifferent to these miseries, which reminded me of those I had suffered in my childhood, when there was no bread in my paternal home. Those sad memories of days without bread and without fire, when I was obliged to work late and sometimes throughout the night

35 Mary Anderson to Bouvier, 20 May 1926; there is an English version of this letter in Bouvier's papers, but with an earlier date, 18 April 1926. See ВнDp/Амв/FJB, Correspondance, Boite 17.2.

36 внDP/Амв/FJв, Correspondance, Boite 17.1.

37 Anderson to Bouvier, 15 January 1925, B HDP/АMB /FJB, Correspondance, Boite 17.2. 
so that my family could eat the following day; all these memories made me stand in solidarity with all the distressing reports I was reading in the newspapers. ${ }^{38}$

Memories of work here become a plane for sustaining class consciousness, and inspiring resistance and political action. It was from the position of an organic intellectual that Bouvier had intervened in the formation of discourses and policies around this major labour issue of her time. In doing so, she particularly referred to the first international conference on industrial home work held in Brussels in 1910, where the International Office for Industrial Home Work was founded. ${ }^{39}$ She became a member of its French branch and represented France as an elected delegate at the second conference held in Zurich in 1912. It was this conference that largely prompted the 1915 law, which attempted to regulate unregulated spheres of work. While giving a concise and clear picture of the international efforts and debates, Bouvier also poignantly pointed to the failure of the syndicalist movement to understand and engage with the problem. "They were not interested in this important question. Their disinterest was carried to the point of completely ignoring the functions of the law and in effect becoming prejudiced against the interests of home-based workers", she wrote. ${ }^{40}$

Bouvier was absolutely furious with the consequences of such indifference, negligence and injustice; she knew from her own experience that industrial home work was a sphere that many women needleworkers would enter at some point in their lives, whether single, married or widowed, and whether or not they worked in workshops and ateliers. It is therefore not surprising that like many other women trade unionists, Bouvier fell out with the leadership of the Confederation General du Travail (CGT). Her Mémoires include a copy of a letter she received on 26 February 1923, through which, and without any prior consultation, her male comrades crudely announced their decision to remove her from the administrative committee of the Clothing Federation, although she was the only woman ever to have been elected to this position. They also asked her to step down from her position as the Vice-President for France of the International Federation for Working Women (IFWW): "I was undesirable on the national and international level", Bouvier bitterly noted. ${ }^{41}$ Writing from London, the IFWw secretary Marion Phillips would express her deep

38 Bouvier, Mes Mémoires, p. 15 o.

39 Ibid., p. 151.

$40 \quad$ Ibid., p. 153.

41 Ibid., pp. 139-40. 
regret, "fully shared by the Executive Board", 42 about the fact that she would no longer represent France. So deep was Bouvier's conflict with the CGT leadership that they even refused to cover her travelling expenses to attend the third International Women Workers' Congress (IWWC) held in Vienna in 1923, and it was this issue that Phillips' letter tried to resolve: 'I am not sure what exactly the situation is about the expenses. I expect that since the CGT won't pay them, you will let me know the total sum so that the Federation can compensate you. It is our duty since you were acting in your role as our Vice-President."43

Although the details of Bouvier's friction with the CGT are not fully apparent in her Mémoires, the letters she exchanged with some of her ex-comrades are revealing. They also contain traces of a bitterness she wished to archive rather than write about. "I do not want to represent a Federation whose executive committee judged and condemned me without allowing me to defend myself", she wrote in response to a request to represent the Federation in the Conseil du Travail in April $1925 \cdot{ }^{44}$ It was at this time that Bouvier threw herself into the historical studies that made her a writer, the topic of the third part of her Mémoires. She bitterly noted, reflecting on her own experience of the French labour movement:

Due to my estrangement from workers' organizations, I was able to work in tranquillity on historical questions which interested me and more particularly on women's work. In the silence of the library and the solitude of my home, I could see the state of inferiority women held within workers' organisations. ${ }^{45}$

Bouvier's multilayered experiences of industrial home work throughout her working life open up new avenues in feminist labour histories. My point here is that feminist analyses of women's work in its various modes and manifestations, classical, Marxist or otherwise, have been dominated by structuralist ideas, concepts and dualisms: waged/unwaged, paid/unpaid, production/reproduction, home/factory, local/global, to name but the obvious. A Hegelian either/ or connects and separates these issues. And yet the phenomenon of industrial home work is much more complex and cannot really fit into any of the boxes or dualisms that have been deployed in attempts to analyse and understand it.

42 Marion Phillips to Bouvier, 13 September 1923, внDр/Амв/FJв, Correspondance, Boite 17.2.

43 Ibid.

44 Bouvier to Camarade Manebus, 13 April 1925, ibid.

45 Bouvier, Mes Mémoires, pp. 145-46. 
What I therefore want to suggest is that the notion of assemblage ${ }^{46}$ can be a useful theoretical lens with which to grasp and analyse the multiplicities and complexities of industrial home work. But what is assemblage?

Unlike closed organisms, structural systems and fixed identities, assemblages do not have any organizing centre; they are rather networks of connections, always in flux, assembling and reassembling in different ways. Assemblages are thus emergent features of relationships and can only function as they connect with other assemblages in a constant process of becoming. Seen in this light, some of the components of the industrial home work assemblage would be labour power, fluctuating salaries and wages, domestic tasks, motherhood, gender relations, love, caring labour, state regulations, legal reforms and trade union politics, amongst others. Drawing on aspects of Deleuze and Guattari's analytics, Manuel DeLanda has further elaborated the theory of assemblages as a new philosophical understanding of social entities that "should account for the synthesis of the properties of a whole not reducible to its parts". ${ }^{4}$ Conceived as a theory of "wholes whose properties emerge from the interactions between parts", ${ }^{48}$ the assemblage approach offered by DeLanda particularly looks into the historically difficult problem of micro/macro relations, and therefore gives "a sense of the irreducible social complexity characterizing the contemporary world". 49

As an assemblage of multiple problems and practices, roughly delineated above, le travail à domicile included capitalist and gender labour relations but was not reduced to these. There were also other issues to be considered. Boris has influentially mapped different sites and contexts of industrial home work conditions in the USA at the turn of the century. ${ }^{50}$ In the context of the French garment industry, Judith Coffin has pointed to "subcontracting, piecework, artisanal autonomy and the regulation of the labour market";51 I would add seasonal unemployment, lack of health insurance and pensions, the problems of widows and of unmarried women workers. To these economic, social, political and cultural components, we should also add emotions and affects, which are densely entangled in the assemblage of social inequality.

46 Gilles Deleuze and Felix Guattari, A Thousand Plateaus: Capitalism and Schizophrenia, trans. Brian Massumi (London, 1988 [1980]).

47 Manuel DeLanda, A New Philosophy of Society: Assemblage Theory and Social Complexity (London, 2006), p. 4.

48 Ibid., p. 5 .

49 Ibid., p. 6.

50 Boris, Home to work.

$5^{1}$ Coffin, The Politics of Women's Work, p. 187. 
Theorized within the framework of the assemblage, women's work emerges as a complex entanglement of some of the components already identified above, which make specific connections with other components within the assemblage, but also develop external relations with components of other assemblages: colonialism, migration, race relations, national and international economic crises, sex work, homelessness, family histories and moral panics, to name but the most striking. It is precisely the complexity of the phenomenon of industrial home work and its multifarious entanglements and connections with capitalism, colonialism and patriarchy that have historically rendered it such a difficult issue to grasp, understand and, most importantly resist. Boris's influential work ${ }^{52}$ has already initiated the need for interdisciplinary conceptualizations of the home/work continuum, so I consider my suggestion of the assemblage as a contribution in continuation of such a line of thought in feminist labour histories.

What, then, are the implications of working with assemblage theories? A central task of the analysis would be to make specific cartographies of situated phenomena and problems, trace the connections they make in order to configure emerging new formations, but also follow their "lines of flight", since for Deleuze and Guattari, society is not so much defined by its molar formations and their dialectical oppositions but rather by what has escaped them, not the molar socio-cultural entities but the molecular counter-formations, the lines of flight. ${ }^{53}$ It is by thus following "lines of flight" in the assemblage of industrial home work that I now consider Jean Bouvier's early theorization of the French lingerie industry as an exemplar of an assemblage avant la lettre.

In the last pages of her Mémoires, Bouvier wrote about the pleasures of intellectual work that she immersed herself in during the fifty-nine years of her long working life and after she had stepped down from her position in the CGT, in 1923. Bouvier's agonistic politics went hand in hand with hard work and intense intellectual activity, all beautifully recounted in her Mémoires, which was the last volume she published, in 1936, after a series of four historical studies on women's work, economics and politics, as already noted above.

\footnotetext{
52 Boris, Home to work.

53 Deleuze and Guattari, A Thousand Plateaus, p. 216.
} 
What were the conditions that made it possible for such creative forces to be unleashed? As Bouvier wrote in her Mémoires, it was the law that regulated the work day to eight hours after the First World War that allowed workers time for intellectual activity. ${ }^{54}$ It was also after the war that Georges Renard, professor of labour history at the Collège de France, took up the task of editing the 58-volume La Bibliothèque sociale des metiers [The Social Library of the Trades]. There were seven volumes on women in this collection: La Lingerie (by Jeanne Bouvier); Fleurs, Plumes, Modes (by Marguerite Boural); La Dentelle (by Mathilde Parat); Les Gens de Maison (by Mme Moll-Weiss); L'Instutrice (by Marguerite Bodin); Tabac et Allumettes (by Mme Claude Réal); and Le Cinéma (by Mme Germaine Dulac). The titles of these seven volumes commissioned to women are very interesting in terms of the gendered cultural politics of the first half of the twentieth century in France, but the mere fact that women were considered to be authors of studies in the history of work is, I think, important in the context of their environment and times. What is also worth noting is that Bouvier was the only woman worker who was asked to write a history of the lingères, an occupational group among French garment workers that was always at the bottom of the strict hierarchy of the trade.

Since the spirit behind Renard's edited collection was that all volumes were to be authored by field experts, the fact that Bouvier was chosen was not surprising. Although she had already become a skilled dressmaker by the time she was asked to write the history of the lingères, a couturière working in highly esteemed Parisian ateliers, she was also a militant activist in the lingerie trade union and a leading figure in the French federation of garment workers. She had served on the Conseil Supérieur du Travail in 19o9, while in 1913 the Labour Minister asked her to carry out a comprehensive review of the conditions of industrial home work in France. Bouvier's status in the French labour aristocracy was thus the end-point of a long process that beautifully unfolds through the pages of her memoir. Yet, the invitation to write a book made her feel utterly out of her depth:

When alone, I was thinking: "M. Georges Renard has been deluded about my value and my knowledge. No, it is not possible for me to accept to write a book, I have always suffered due to my ignorance. [...] How can I write the history of the lingerie and its workers?" It is true that in the course of my long career as a trade unionist I got to know the social questions for 
better or for worse; but to translate them on paper and compose them in a book seemed an insurmountable task! ${ }^{55}$

Despite the difficulty, however, Bouvier threw herself into the pleasures of research, and not only did she manage to write a history of lingerie and lingères, but when she had completed working on the manuscript and proudly took it to the editor, she actually found that she had to reduce its length as there was a page limit she had forgotten about. "I, who had thought myself incapable of writing a book because I didn't know how to put it together, had gone beyond the prescribed limit!"56 she wrote in astonishment. The book comprises three parts. The first looks at the history of lingerie in terms of its antiquity, the sumptuary and protective laws, and the different pieces of lingerie. The second part is about the professional organization of lingères in the old regime up until the 1789 revolution, while the third part follows the journey of lingerie in the nineteenth and twentieth centuries. Since the initial manuscript as well as the author's notes have been kept among Bouvier's Fonds, today's researcher can see not only the amount of work that had to be removed from the final version, but also the fine character of Bouvier's final draft in terms of content as well as literary style. ${ }^{57}$

What is particularly interesting in the first part of the book is the meticulous way in which Bouvier presented the different historical phases of the trade, but also how carefully she traced the genealogy of various pieces of lingerie, highlighting their importance in the history of the garment industry. In tracing the micro-histories of garments, Bouvier used a variety of sources including archaeological evidence, such as mirror paintings and hieroglyphics. She also drew on literature, including theatrical playscripts and the Bible, as well as a wide range of archival sources that she studied at the French National Archives. Bouvier's meticulous research is thus an early contribution in the now bursting field of cultural studies, but it is more than that: in tracing the rich genealogy of her trade, she created an archive that would sustain and support women workers' awareness of their active contribution in the history of civilization. Also, it was not only the history of clothes and fashion in general, and lingerie in particular, that Bouvier was interested in. She also studied the economic history of the trade, focusing specifically on the emergence of laws regulating the fashion industry in terms of consumption. In doing so, she examined gender- and class-driven strategies and regulations, but also traced

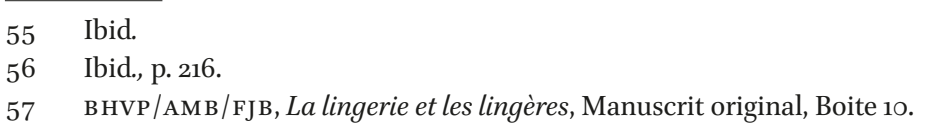


early signs of biopolitics as well as the effects of an emerging global market on the lives of the working people.

Apart from the economics, technological changes and diversity of products in the lingerie industry, Bouvier also looked into the history of its women workers, the lingères. According to the guild records there were around 700 lingères mistresses in Paris before the revolution, but the total number of workers had never been calculated, Bouvier observed. ${ }^{58}$ As Clare Crowston has noted in her history of the seamstresses' guild under the old regime, clandestine production was part of the labour economy in the clothing industry, but it went completely out of control after the dissolution of the guilds and the domination of free market forces. ${ }^{59}$ Thus, the difficulty of knowing the exact number of lingères working in France in general, and in Paris in particular, was recorded as a recurrent problem in Bouvier's study of the history of the trade in the nineteenth and twentieth centuries. In support of her argument, she pointed to how lingères were absent from previous investigations, and particularly to discrepancies and inconsistencies in the national registers and records. For example, only 300 lingères were recorded across France in the period $1840-45$, a ridiculous number especially when compared with the 10,110 lingères recorded in 1851 in Paris alone. ${ }^{60}$

It was not only the number of lingères, but also their wages and their social position that were obscured. It was thanks to some "fraternal spirits that their misery, that all their sufferings occasionally came to light", Bouvier noted. ${ }^{61}$ She drew on Charles Dupin's ${ }^{62}$ studies to highlight the fact that in the course of merely five years, between 1815 and 1820, the famous Salpêtrière had hospitalised 2,641 women for having lost their minds. Among them were 735 lingères and couturières, 104 embroiderers and 112 laundresses. There were also 247 workers from other trades and 4 women who were property owners. ${ }^{63}$ These numbers showed the alarming effects of industrial home work on women needleworkers, and created the background for female labour to become the predominant social problem referred to in nineteenth-century discourses and practices. ${ }^{64}$

\footnotetext{
$5^{8} \quad$ Bouvier, La lingerie et les lingères, p. 231.

59 Claire Haru Crowston, Fabricating Women: The Seamstresses of Old Regime France, 16751791 (London and Durham, 2001).

6o Bouvier, La lingerie et les lingères, p. 238.

61 Ibid.

62 Charles Dupin was a moral economist, whose book, Forces productives et commerciales de la France, published in 1827 , had made an impression in the first decades of the nineteenth century.

63 Bouvier, La lingerie et les lingères, p. 232

64 See Jules Simon, L'ouvrière (Paris, 1862).
} 
In trying to unearth the socio-historical, economic and political conditions that created such unbearable conditions for the lingères, Bouvier devoted a whole chapter to travail à domicile, carefully defining its nature, function and economics:

The travail à domicile is work distributed to workers by an industrialist or a merchant, who then sell the manufactured objects. It is veritable industrial work. In opposition to work at the atelier, which is called centralized work or agglomerated industry, M. Georges Renard called the travail à domicile decentralized work or dispersed industry. ${ }^{65}$

In defining the term 'industrial home work', Bouvier further examined the gendered genealogy of this trade, tracing it back to the Middle Ages, when St Bernadier de Sienne had written: "Oh women, women! If one took one of your garments and wrung it, they would see the blood of God's creatures coming out of it." 66 But although the history of the trade goes well back in history, it was only in the middle of the nineteenth century, in 1858 , that a comprehensive review of the conditions of lingères in Lille was conducted by M. Auvray. This study gives a full-fledged description of the lingères' actual labour process, which included pulling threads, fitting pattern pieces, matching seams and stitching them together. ${ }^{67}$ Auvray's study also included an account of the lingères' daily activities, particularly emphasizing the intensity of their working hours: "The worker who dedicates 10 hours a day to her task earns 1.75 francs per day but she has to deduct a quarter of it for periods of unemployment or times of illness." ${ }^{68}$ There was also an exact calculation of the time the workers needed to clean their homes, do their laundry, and make and mend the family's clothes. Finally, it had details of their daily meals as well as the overall organization of their household including room plans, furniture and home ware.

Apart from the biopolitics of this early study of the lingerie, what is striking about it is that home and work could not be separated from the very beginning of this trade: industrial home work was presented as an assemblage where waged and unwaged labour as well as productive and reproductive practices were tightly interwoven within the political economy of women's work, and has remained so till today as already noted in the previous section. There is a rich body of feminist literature around these issues, where Marxist analyses

65 Bouvier, La lingerie et les lingères, pp. $25^{2-53}$.

66 Cited in ibid., p. 254.

67 Ibid., p. 264.

68 Ibid., p. 265 . 
have been influential in the way we make sense of the complexities of women's labour practices. Questions that still remain central in this area derive from different philosophical approaches to the concepts of work, reproduction and care, as well as the thorny relations between women's oppression, gendered labour and the class politics of the left. ${ }^{69}$ In the context of this literature, Kathi Weeks has observed that "there is a lack of attention to the lived experiences and political textures of work within political theory".70

Bouvier's study addressed such omissions not just in political theory, but also in labour history, fighting against abstract representations of work in general and gendered labour in particular. As Katerina Kolozova has succinctly noted, abstraction lies at the heart of Marx's critique of capitalist exploitation in general and fetishization in particular. ${ }^{71}$ When work loses the visceral elements of its reality, "the physical and sensuous" according to Marx, ${ }^{72}$ it becomes a symbolic representation "more real that the real".73 It was precisely this process that Marx criticized in his economic and political writings, seeking to protect the real from the speculations of fetishism, Kolozova has argued: "Marxism understood as a philosophical project aims to reclaim the real identified with matter and emancipate it from the dictate of the idea or of the speculative."74

The material reality of labour is at the heart of Bouvier's analysis in her history of lingerie, drawing on the lived experiences of lingères as well as her own memories of working as a lingère. The lingères' voices were thus crucial to Bouvier's project, particularly as they emerged from the documents she gathered during a four-year inquiry (1904-08) into the conditions of industrial home workers that she conducted as part of her research. This inquiry covered 24 administrative areas across the country and 2,300 respondents from all areas of the lingerie industry, including entrepreneurs, contractors,

69 Discussion of these issues goes well beyond the scope of this chapter and has been done elsewhere. See, amongst others, Kathy Weeks, The Problem with Work: Feminism, Marxism, Antiwork Politics, and Postwork Imaginaries (Durham, 2011); Silvia Federici, Revolution at Point Zero: Housework, Reproduction and Feminist Struggle (Oakland, 2012); Janet Newman, Working the Spaces of Power: Activism, Neoliberalism and Gendered Labour (London, 2012); Rafaella Sarti, Anna Bellavitis and Manuela Martini (eds), What is Work? Gender at the Crossroads of Home, Family and Business from the Early Modern Era to the Present (New York and London, 2018).

70 Weeks, The Problem with Work, p. 2.

71 Katerina Kolozova, Towards a Radical Metaphysics of Socialism: Marx and Laruelle (Brooklyn, 2015).

72 Karl Marx, "Theses on Feuerbach" [1845], in Karl Marx and Friedrich Engels, The German Ideology, trans. Roy Pascal (London, 1938).

73 Kolozova, Towards a Radical Metaphysics of Socialism, p. 2.

74 Ibid., p. 4. 
subcontractors and workers. According to Bouvier, the results of this inquiry showed that the conditions of the lingères at the beginning of the twentieth century were actually worse than in $185^{8}$, thus highlighting the importance of understanding historical discontinuities and their effects while making sense of contemporary realities:

Here are the results of research on the situation of some women workers. No. 6o, Paris. The worker is a 35-year-old widow and has a little daughter. She has been working for some years. [...] She works between 15 and 18 hours per day. She has very little work during the summer months. [...] At the time of the research she was expecting to be evicted on the grounds of a small debt owed to the landlord. In the evening or on the next day she would find herself homeless. Her troubles prevented her from responding to certain questions posed by the researcher. ${ }^{75}$

Bouvier sketched pen-portraits of lingères whose life histories and work trajectories more or less followed similar paths: they were all between 30 and 40 years old, mostly widows or abandoned by their husbands and with children to look after. They all worked between 14 to 18 hours per day, were very poorly paid and went through long periods of unemployment.

No. 189. Mme, R... has been a lingère since her childhood. She is a widow with two daughters; the youngest is 11 years old and is under her custody [...] she works until her forces abandon her. This excessive work combined with deprivation have so weakened her that at the time of the research she was found lying in bed, sewing. Her situation is so miserable that she cannot feed her daughter, who gets free breakfast at the canteen of the communal school. [...] She lives in a single room of an old house with narrow, filthy corridors. ${ }^{76}$

When asked about their working hours, most lingères would say that they worked "till my forces abandon me", 77 while they could not answer the question regarding how they organized their annual expenses: "This is not at all my way, sir $[\ldots]$ every day earns its bread". ${ }^{78}$ In the case of younger lingères, the route of sex work would also emerge in their narrative: "With what one

\footnotetext{
75 Bouvier, La lingerie et les lingères, pp. 275-76.

76 Ibid., pp. $277-78$.

77 Ibid., p. 299 .

78 Ibid., p. 277 .
} 
can earn in Saint-Omer, many women who are not aided by a man, husband or lover cannot live without prostitution", said a 25-year-old lingère from Saint Omer who worked alongside her older sister 14 hours a day from March till October. ${ }^{79}$ Bouvier compared her story with figures from a senior trade unionist which confirmed that 8 o per cent of the young women and 30 per cent of the married lingères in Saint-Omer were involved in sex work to make ends meet, and that there was a high number of teenage mothers in the area. ${ }^{80}$

Apart from the voices of women workers that find expression in Bouvier's case studies, what is also staged in her analysis is the debate between atelier work and home-based work. "Why do some bosses prefer the atelier as a workplace?" she asks, listing five arguments in support of the atelier: (i) production is more regular and sure; (ii) the process is quicker; (iii) the output is of higher quality; (iv) the quantity of output is larger; (v) faults and errors are more efficiently fixed..$^{81}$ She then cites those who favour industrial home work, arguing that (i) it is more economic as there are no estate expenses and the wages are lower; (ii) there are no strikes or protective legislation to grapple with; (iii) the work is more regular and the articles are better made; (iv) it is beneficial for women as it allows them to combine work with running a household; (v) the working hours are more flexible..$^{82}$ According to Bouvier, then, the main arguments in favour of industrial home work were that it was totally unregulated and not subject to any social laws or labour legislation. ${ }^{83}$ It was precisely the need for regulation and control that became the object of trade union interventions at the beginning of the twentieth century, and it was this history that Bouvier also looked at in her study.

Moreover, as part of her archival documents, Bouvier's Fonds at the Historical Library of the City of Paris include two important boxes (Boîtes 18 and 19) with over 1,200 folios comprising the genealogical dispositif of the travail à domicile, quite simply its grid of intelligibility. As Foucault has configured it, a dispositif is a system of relations that can be established between heterogeneous elements, "discourses, institutions, architectural arrangements, regulations, laws, administrative measures, scientific statements, philosophic propositions, morality, philanthropy [...] the said as well as the unsaid". ${ }^{4}$ In

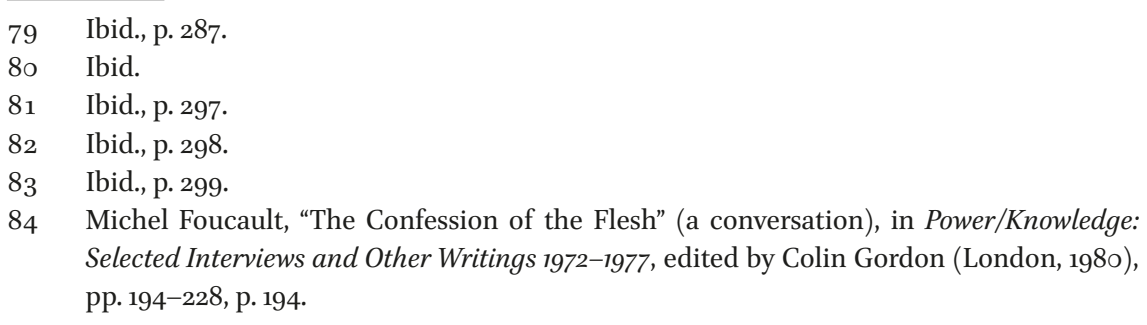


this light, the dispositif of the travail à domicile that Bouvier carefully archived and organized consists of preparatory material for the 1915 law, its full content, parliamentary documents and ministerial decrees, and finally, projects for its future amendments. It also includes a detailed record of the activities of the French branch of the International Office for the travail à domicile, drafts of future international projects, Bouvier's personal notes and reflections on the problem, and an extended body of correspondence with national and international figures, institutions and agencies.

Besides the dispositif of the travail à domicile, whose genealogy has yet to be written, Bouvier's comprehensive archive of otherwise inaccessible and dispersed documents demonstrate the depth and seriousness of her involvement with this serious labour problem, not only on an intellectual level, but also in terms of minutiae at the legal and administrative level. As the editors of the 1983 publication of her Mémoires have noted, Bouvier was one of the originators of the 1915 law, the first international legislative attempt to regulate the travail à domicile, and nobody knew better than her how to catalogue and archive its multiple and complex files and documents. ${ }^{85}$

Bouvier chose to complete her study of the lingères with a genealogy of their struggles in a very Foucauldian way of writing the history of her present as a political activist in the lingères' syndicate, but also in a Deleuzian way of following "lines of flight". Choosing the 1789 French revolution as her genealogical emergence, the point when things erupted as events in the course of history, ${ }^{86}$ Bouvier noted that the lingères were amongst the best organized trade bodies in Paris, and despite the admission of men workers, the union was totally managed by women only. The lingères reunited after the 1848 revolution to demand their own share in the right to work that was the rallying cry of the Second Republic. As I have elsewhere discussed at length, their leaders during the period of the July Monarchy (1830-48) included major figures of the first autonomous feminist movement in France, such as Désirée Véret-Gay, Marie-Reine Guindorf and Jeanne Deroin. ${ }^{87}$ The brutal repression of the 1848 revolution and the political persecution of all workers' associations and their leaders delayed the professional organization of the lingères, and it was only after 1870, during the Third Republic, that they were able to unionize again in the Syndicat de la Chemiserie-Lingerie, founded in 1873 .

Women workers' right to form a union was neither easy nor straightforward. Unsurprisingly, they were initially omitted from appeals to workers to form

85 Bouvier, Mes Mémoires, p. 273 n.41.

86 Foucault, "Nietzsche, Genealogy, History", p. 83.

87 See Tamboukou, Sewing, Fighting and Writing. 
unions after the 1870 war. In her genealogy Bouvier has included a letter by Shaller, a proletarian woman, who wrote to "Citizen Barberet", the editor of the column Bulletin du Travail in the radical republican newspaper Le Rappel, on 29 October 1873: "How is it that you daily defend the workers' rights in Le Rappel with such authority and you have completely abandoned to this day one of the most interesting and exploited class, the women workers?"88 Barberet swiftly responded that women were included in his appeals, and a wider movement for the organization of women workers was set in motion that ended in the founding of the Chambre Syndicale de lingères, couturières, brodeuses et confectionneuses, in May 1874.

What was particularly important in the foundation of this first Chambre Syndicale is that for the first time, women needleworkers surpassed intralabour differences and by coming together they showed that women's work was always crossing the boundaries between specialities and hierarchies within their trade. Most importantly, they showed that the spatial division of women's labour was always blurred and that there could be no clear distinction between atelier work and home-based work. In uniting their forces, women workers fought for collective contracts that included regulation of their working hours as well as the stipulation of minimum wages and salaries. Such victories only became possible in the first decades of the twentieth century as a result of militant strikes in the garment industry, where the seamstresses took centre stage.

In writing the history of lingerie and lingères, Bouvier drew on facts and figures of previous investigations, but she carefully avoided the trap of pathologizing women's work and of victimizing the seamstress. There are thus four outstanding aspects of her study, as briefly presented above: (i) a careful mapping of the economics, structures and problems of the phenomenon of industrial home work, including its international context; (ii) close attention to the minutiae of the lingères' daily activities and labour practices; (iii) a genealogy of the lingères' trade union movement and its struggles; and (iv) a very early attempt to collect and archive case studies from the lingères' lived experiences of work.

I therefore suggest that, since many of the questions that were raised at the turn of the nineteenth century are both pertinent and unresolved even today, a genealogical investigation through the lens of assemblage theories can offer rich and useful insights in contemporary research and policies. To do this, however, we need to make cartographies of particular questions and issues within specific geopolitical contexts. The assemblage approach does not offer 
generic solutions and directions but rather encourages topological sensibilities and cartographies. What most importantly emerge from this approach are discernible traces of resistance and ultimately a deconstruction of the myth that women workers in the long history of industrial home work have been passive victims of oppression, rather than agents actively pursuing their right to life and to work. Bouvier's lived experiences, her agonistic politics and her careful historical studies on women's work are a sound counter-example of such mythologies, discourses and narratives. 